<smiles>CNC1=NC(=O)C([C@@H](C)c2c[nH]c3ccccc23)O1</smiles>

(-)-indolmycin<smiles>Oc1ccc(CC(O)C(O)Cc2c[nH]c3ccccc23)cc1</smiles>

(+)-diolmycin A2
Figure 1: Oxygen-functionalized indole compounds.

Meanwhile, our group has developed resin-supported peptide catalysts (Figure 2) for several organic reactions in aqueous media [30-37]. Since these catalysts can be applicable for the FCAA reaction toward $\alpha, \beta$-unsaturated aldehydes through iminium intermediates [32,37], and an asymmetric $\alpha$-oxyamination of aldehydes via enamines [33], they are expected to be suitable for a one-pot sequential reaction to make the chiral indoles mentioned above. Herein, we report on an enantioselective synthesis of oxygenated indole compounds through a onepot sequential FCAA/ $\alpha$-oxyamination catalyzed by the resinsupported peptide.

\section{Pro-D-Pro-Aib-Trp-Trp-(AA) $)_{n}-\mathrm{O}$}

$$
\begin{aligned}
(\mathrm{AA})_{n} & =\left\{\begin{array}{l}
(\mathrm{Leu})_{25.4} \\
(\text { Leu-Leu-Aib })_{2}
\end{array}\right. \\
-\mathbf{O} & =\text { amphiphilic resin }
\end{aligned}
$$

Figure 2: Resin-supported peptide catalyst.
In a one-pot sequential reaction, the compatibility of reaction conditions in each step is important. Previously, we have reported a reaction system for the asymmetric $\alpha$-oxyamination of aldehydes catalyzed by a peptide and an oxidizing enzyme, laccase $[36,38]$. Because the reaction conditions for that system are mild without employing a strong oxidant, we envisaged that the sequential FCAA/ $\alpha$-oxygenation could be attained by adopting the peptide-and-laccase-cocatalyzed oxyamination, even though indoles are generally prone to be oxidized $[39,40]$. By considering that enzymes promote reactions efficiently under aqueous conditions, we thought it necessary to conduct the one-pot reaction in aqueous media. Therefore, the reaction sequence shown in Table 1 was first examined in water. After the FCAA by peptide catalyst 1 , the $\alpha$-oxyamination was successively performed by adding 2,2,6,6-tetramethylpiperidin1-oxyl (TEMPO) and laccase directly to the reaction mixture. The desired two-step reaction product 4 was obtained with syn/anti ratio of 75:25, and the ee value of the syn diastereomer was $96 \%$ (Table 1, entry 1 ). It is noteworthy that the ee of the major diastereomer was higher than that of each single reaction $[33,37]$. Such enantio-enrichment is generally caused in consecutive catalytic asymmetric reactions through the formation of diastereomeric pairs $[17,41]$. From the viewpoint of reaction efficiency, the conversion in each step was low, presumably because of poor solubility of the substrates in water. Thus, use of the organic cosolvent THF was examined (Table 1, entries 2 to 5). As a result, the solvent system $\mathrm{H}_{2} \mathrm{O}$ /THF 2:1 was regarded as the optimum (Table 1 , entry 4 ). When the reaction was performed under conditions with a higher content of THF,

Table 1: One-pot sequential Friedel-Crafts-type alkylation/a-oxyamination.

Pro-D-Pro-Aib-Trp-Trp-(Leu-Leu-Aib) ${ }_{2}-\mathrm{O}(1)$

\begin{tabular}{|c|c|c|c|c|}
\hline entry & solvent & $2: 3: 4^{a}$ & syn/anti of $\mathbf{4}^{a}$ & $\begin{array}{l}\text { ee }[\%]^{\mathrm{b}} \text { of syn-isomer } \\
\text { (anti-isomer) }\end{array}$ \\
\hline 1 & $\mathrm{H}_{2} \mathrm{O}$ & $67: 14: 19$ & $75: 25$ & $96(64)$ \\
\hline 2 & $\mathrm{H}_{2} \mathrm{O} / \mathrm{THF}$ 9:1 & $32: 17: 51$ & $73: 27$ & $96(62)$ \\
\hline 3 & $\mathrm{H}_{2} \mathrm{O} / \mathrm{THF} 5: 1$ & $44: 10: 46$ & $76: 24$ & $97(57)$ \\
\hline 4 & $\mathrm{H}_{2} \mathrm{O} / \mathrm{THF} 2: 1$ & $17: 5: 78$ & $75: 25$ & $98(56)$ \\
\hline 5 & $\mathrm{H}_{2} \mathrm{O} / \mathrm{THF} 1: 1$ & $15: 85: 0$ & - & - \\
\hline
\end{tabular}

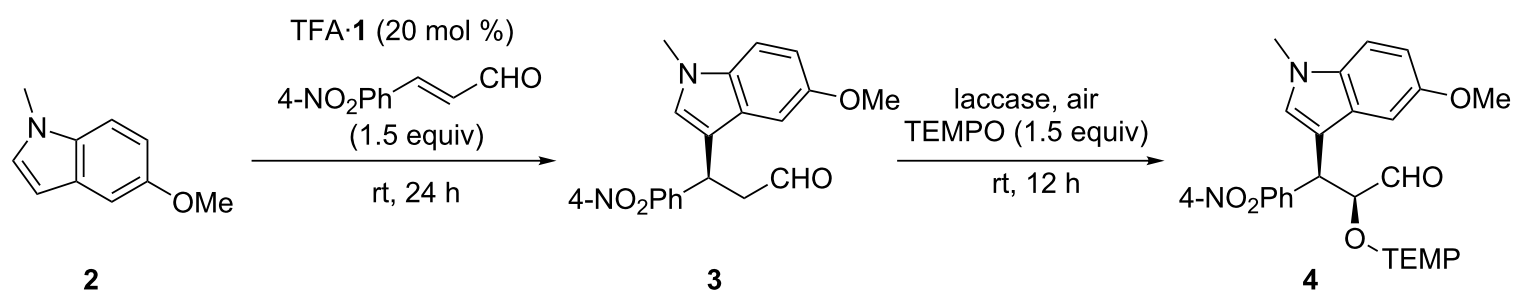

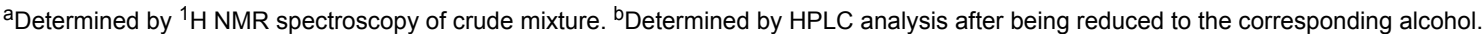


such as in the case of $\mathrm{H}_{2} \mathrm{O} / \mathrm{THF} 1: 1$, the peptide/laccasecatalyzed oxidation did not proceed at all, due to inactivation of laccase (Table 1, entry 5). This indicates the importance of water as a solvent for realization of the present sequential reaction.

To elucidate the origin of the stereocontrol in the present sequential reaction, the following control experiment was conducted. After the first FCAA reaction, peptide catalyst 1 was removed by filtration and another peptide catalyst $\mathbf{5}$, which is the enantiomer of $\mathbf{1}$, was added to promote the $\alpha$-oxyamination (Scheme 1). In this case, the anti-isomer was obtained as a major diastereomer, and the ee value of the anti-product was high. The reversal of the diastereoselectivity along with the high ee of the major diastereomer demonstrates that the stereochem- ical course of the second-step $\alpha$-oxyamination was determined mainly by the stereostructure of the peptide catalyst rather than by the chirality of the intermediate 3 .

Finally, other substrates were tested in the present one-pot sequential reaction system (Table 2). Several substituted indoles gave the products with high enantioselectivity (Table 2, entries 1 to 3 ). As an $\alpha, \beta$-unsaturated aldehyde, 3-nitrocinnamaldehyde was also applicable (Table 2, entry 4). Other than indoles, a pyrrole compound could be employed as a starting nucleophile in the sequential FCAA/ $\alpha$-oxyamination (Table 2, entry 5 ).

In conclusion, the FCAA followed by the asymmetric $\alpha$-oxyamination was realized in a one-pot reaction, by using a peptide catalyst and laccase. This sequential reaction afforded the

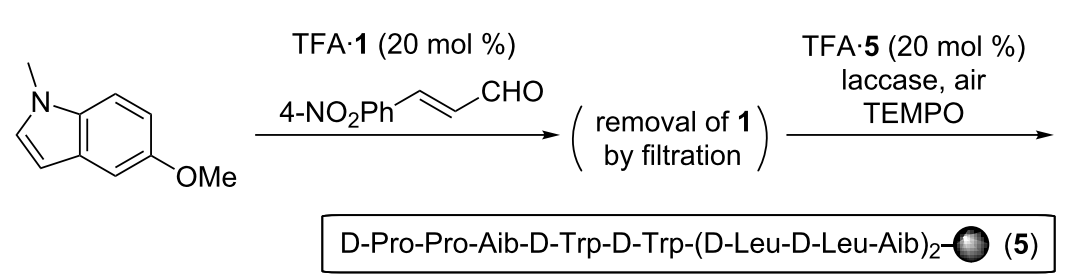

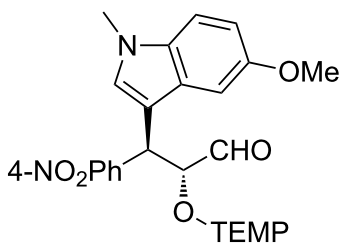

syn $/$ anti $=23: 77$

syn: $65 \%$ ee, anti: $96 \%$ ee

Scheme 1: Effect of the stereostructure of the peptide catalyst.

Table 2: Examples of the one-pot synthesis of oxygenated heteroaromatic compounds

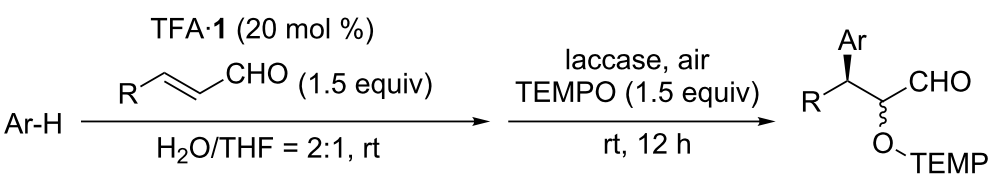

\begin{tabular}{|c|c|c|c|}
\hline entry & product & time $(\mathrm{h})$ of first step & $\begin{array}{l}\text { ee }[\%]^{\mathrm{C}} \text { of syn-isomer } \\
\text { (anti-isomer) }\end{array}$ \\
\hline
\end{tabular}

1<smiles>COc1ccc2c(c1)c(C(CO)C(C=O)OC(C)C)cn2C</smiles>

4<smiles>[Y6]O[C@@H](C=O)[C@@H](c1ccccc1)c1c[nH]c2ccc(OC)cc12</smiles> 
Table 2: Examples of the one-pot synthesis of oxygenated heteroaromatic compounds. (continued)

3<smiles>Cn1cc(C(OC#N)C(C=O)OC#N)c2ccccc21</smiles>

7<smiles></smiles>

8<smiles>Cn1cccc1[C@H](CO[N+]#N)[C@H](C=O)OC#N</smiles>

5
57

$75: 25$

$98(55)$

alsolated yield. ${ }^{b}$ Determined by ${ }^{1} \mathrm{H}$ NMR spectroscopy. ${ }^{\mathrm{c}}$ Determined by HPLC analysis after being reduced to the corresponding alcohol.

oxygen-functionalized indole derivatives with high optical purity. By utilizing the wide applicability of peptide catalysts in aqueous media, and mild reaction conditions for enzymatic reactions, various types of new sequential reactions can be expected for producing highly functionalized compounds.

\section{Supporting Information}

\section{Supporting Information File 1}

Typical experimental procedure, spectroscopic data for products, determination of stereochemistry, ${ }^{1} \mathrm{H}$ and

${ }^{13} \mathrm{C}$ NMR spectra and HPLC charts.

[http://www.beilstein-journals.org/bjoc/content/ supplementary/1860-5397-8-152-S1.pdf]

\section{Acknowledgement}

This work was partially supported by a Grant-in-Aid for Young Scientists (B) (23750171 for K. A.) from the Japan Society for the Promotion of Science.

\section{References}

1. Somei, M.; Yamada, F. Nat. Prod. Rep. 2004, 21, 278-311. doi:10.1039/b212257j

2. Ruiz-Sanchis, P.; Savina, S. A.; Albericio, F.; Álvarez, M. Chem.-Eur. J. 2011, 17, 1388-1408. doi:10.1002/chem.201001451

3. Saxton, J. E. Nat. Prod. Rep. 1997, 14, 559-590. doi:10.1039/np9971400559
4. Jørgensen, K. A. Synthesis 2003, 1117-1125. doi:10.1055/s-2003-39176

5. Bandini, M.; Melloni, A.; Umani-Ronchi, A. Angew. Chem., Int. Ed. 2004, 43, 550-556. doi:10.1002/anie.200301679

6. Bandini, M.; Melloni, A.; Tommasi, S.; Umani-Ronchi, A. Synlett 2005, 1199-1222. doi:10.1055/s-2005-865210

7. Bandini, M.; Eichholzer, A. Angew. Chem., Int. Ed. 2009, 48, 9608-9644. doi:10.1002/anie.200901843

8. You, S.-L.; Cai, Q.; Zeng, M. Chem. Soc. Rev. 2009, 38, 2190-2201. doi:10.1039/b817310a

9. Bartoli, G.; Bencivenni, G.; Dalpozzo, R. Chem. Soc. Rev. 2010, 39 , 4449-4465. doi:10.1039/b923063g

10. Terrasson, V.; de Figueiredo, R. M.; Campagne, J. M. Eur. J. Org. Chem. 2010, 2635-2655. doi:10.1002/ejoc.200901492

11. Zeng, M.; You, S.-L. Synlett 2010, 1289-1301. doi:10.1055/s-0029-1219929

12. Enders, D.; Grondal, C.; Hüttl, M. R. M. Angew. Chem., Int. Ed. 2007, 46, 1570-1581. doi:10.1002/anie.200603129

13. Walji, A. M.; MacMillan, D. W. C. Synlett 2007, 1477-1489. doi:10.1055/s-2007-980382

14. Yu, X.; Wang, W. Org. Biomol. Chem. 2008, 6, 2037-2046. doi:10.1039/b800245m

15. Grondal, C.; Jeanty, M.; Enders, D. Nat. Chem. 2010, 2, 167-178. doi:10.1038/nchem.539

16. Ramachary, D. B.; Jain, S. Org. Biomol. Chem. 2011, 9, 1277-1300. doi:10.1039/c0ob00611d

17. Huang, Y.; Walji, A. M.; Larsen, C. H.; MacMillan, D. W. C. J. Am. Chem. Soc. 2005, 127, 15051-15053. doi:10.1021/ja055545d

18. Enders, D.; Narine, A. A.; Toulgoat, F.; Bisschops, T. Angew. Chem., Int. Ed. 2008, 47, 5661-5665. doi:10.1002/anie.200801354

19. Chi, Y.; Scroggins, T.; Fréchet, J. M. J. J. Am. Chem. Soc. 2008, 130, 6322-6323. doi:10.1021/ja8013456 
20. Simmons, B.; Walji, A. M.; MacMillan, D. W. C. Angew. Chem., Int. Ed. 2009, 48, 4349-4353. doi:10.1002/anie.200900220

21. Routien, J. B. J. Bacteriol. 1966, 91, 1663.

22. Werner, R. G.; Thorpe, L. F.; Reuter, W.; Nierhaus, K. H. Eur. J. Biochem. 1976, 68, 1-3. doi:10.1111/j.1432-1033.1976.tb10758.x

23. Tabata, N.; Tomoda, H.; Takahashi, Y.; Haneda, K.; Iwai, Y.; Woodruff, H. B.; Ōmura, S. J. Antibiot. 1993, 46, 756-761. doi:10.7164/antibiotics.46.756

24. Brown, S. P.; Brochu, M. P.; Sinz, C. J.; MacMillan, D. W. C. J. Am. Chem. Soc. 2003, 125, 10808-10809. doi:10.1021/ja037096s

25. Zhong, G. Angew. Chem., Int. Ed. 2003, 42, 4247-4250. doi:10.1002/anie.200352097

26. Hayashi, Y.; Yamaguchi, J.; Hibino, K.; Shoji, M. Tetrahedron Lett. 2003, 44, 8293-8296. doi:10.1016/j.tetlet.2003.09.057

27. Sibi, M. P.; Hasegawa, M. J. Am. Chem. Soc. 2007, 129, 4124-4125. doi:10.1021/ja069245n

28. Kano, T.; Mii, H.; Maruoka, K. Angew. Chem., Int. Ed. 2010, 49, 6638-6641. doi:10.1002/anie.201002965

29. Simonovich, S. P.; Van Humbeck, J. F.; MacMillan, D. W. C. Chem. Sci. 2012, 3, 58-61. doi:10.1039/c1sc00556a

30. Akagawa, K.; Akabane, H.; Sakamoto, S.; Kudo, K. Org. Lett. 2008, 10, 2035-2037. doi:10.1021/ol800031p

31. Akagawa, K.; Akabane, H.; Sakamoto, S.; Kudo, K. Tetrahedron: Asymmetry 2009, 20, 461-466. doi:10.1016/j.tetasy.2009.02.036

32. Akagawa, K.; Yamashita, T.; Sakamoto, S.; Kudo, K. Tetrahedron Lett. 2009, 50, 5602-5604. doi:10.1016/j.tetlet.2009.07.071

33. Akagawa, K.; Fujiwara, T.; Sakamoto, S.; Kudo, K. Org. Lett. 2010, 12, 1804-1807. doi:10.1021/ol100415h

34. Akagawa, K.; Fujiwara, T.; Sakamoto, S.; Kudo, K. Chem. Commun. 2010, 46, 8040-8042. doi:10.1039/c0cc02301a

35. Akagawa, K.; Kudo, K. Adv. Synth. Catal. 2011, 353, 843-847. doi:10.1002/adsc.201000805

36. Akagawa, K.; Kudo, K. Org. Lett. 2011, 13, 3498-3501. doi:10.1021/ol2012956

37. Akagawa, K.; Suzuki, R.; Kudo, K. Adv. Synth. Catal. 2012, 354, 1280-1286. doi:10.1002/adsc.201100950

38. Witayakran, S.; Ragauskas, A. J. Adv. Synth. Catal. 2009, 351, 1187-1209. doi:10.1002/adsc.200800775

39. Kolundzic, F.; Noshi, M. N.; Tjandra, M.; Movassaghi, M.; Miller, S. J. J. Am. Chem. Soc. 2011, 133, 9104-9111. doi:10.1021/ja202706g

40. Ganachaud, C.; Garfagnoli, V.; Tron, T.; lacazio, G. Tetrahedron Lett. 2008, 49, 2476-2478. doi:10.1016/j.tetlet.2008.02.021

41. Appayee, C.; Brenner-Moyer, S. E. Org. Lett. 2010, 12, 3356-3359. doi:10.1021/ol101167z

\section{License and Terms}

This is an Open Access article under the terms of the Creative Commons Attribution License

(http://creativecommons.org/licenses/by/2.0), which permits unrestricted use, distribution, and reproduction in any medium, provided the original work is properly cited.

The license is subject to the Beilstein Journal of Organic Chemistry terms and conditions:

(http://www.beilstein-journals.org/bjoc)

The definitive version of this article is the electronic one which can be found at:

doi:10.3762/bjoc. 8.152 